\title{
Investigation and Classification of Personal Constructs Representing Ideal Counselor from Insider Perspective
}

\author{
Ismail Sanberk \\ Correspondence: Ismail Sanberk, Faculty of Education, Department of Psychological Counseling and Guidance, \\ Cukurova University, Adana, Turkey.
}

Received: April 12, 2016 Accepted: April 22, $2016 \quad$ Online Published: May 9, 2016

doi:10.11114/jets.v4i8.1543

URL: http://dx.doi.org/10.11114/jets.v4i8.1543

\begin{abstract}
The main objective of this study is to determine the personal constructs of psychological counselors $(\mathrm{N}=60)$ when they characterize their colleagues, effective psychological counselors and self-psychological counseling competence through repertory grid technique. Analysis of the data gathered through repertory grid technique demonstrates that participants generally most characterize counselors and effective counselors with professional qualification, professional background, professionalism, experience which are personal constructs. In addition, counselors' current perception of themselves, their ideal-self and the distance between what they attribute to as ideal and non-ideal was obtained with cluster analysis. The paired sample t-test results showed that counselors view themselves significantly distant from both ideal and non-ideal counselor profiles. They tend to form a clearer opinion of what type of counselor they do not want to become, while they are inclined to be uncertain about what type of counselor they want to become.
\end{abstract}

Keywords: effective counselor, personal constructs, repertory grids, counselor perspective, supervision

\section{Introduction}

There are few studies regarding the qualities that counselors should possess and the possible impacts that these qualities have on the process of psychological counseling (Garfield, 1997; Okishii, Lambert, Nielsen \& Ogles, 2003; Beutler, Malik, Alimohamed, Harwood, Talebi, Noble \& Wong, 2004).The relatively existing limited research attempts to establish the qualities that an ideal counselor should have from an outsider perspective (Tscheulin 1982; Jennings \& Skovholt, 1999; Skovholt \& Jennings, 2004). Therefore, the determination of the qualities are mostly based on supervisor, colleague, client and researcher perspectives. It is also possible to examine the qualities of an ideal counselor from their own perspective as well as to what extent they possess these qualities. However, the studies based on the counselors' own perception are scanty (Norcross \& Prochaska, 1982; Skovholt \& Rønnestad, 1995; Sherman \& Thelen, 1998). According to Larson and Daniels (1998), counselor self-evaluation should be taken into consideration when it comes to the qualities of an effective psychological counselor.

Counselor's personal constructs about the qualities of the ideal counselor, and their self-perception as to what extent they have these qualities can be examined by means of the Personal Construct Theory and Repertory Grid Technique based on this theory developed by Kelly (1955-1991). This technique is based on the theoretical understanding which objectively identifies reality as an output of human consciousness. There are two components involved in the Repertory Grid Technique: element and personal construct. While elements are people, incidents or situations that have meaning for certain individuals, personal construct is a tendency that people possess while distinguishing between incidents, situations or people (Fromm, 1995; Fransella, Bell \& Bannister, 2004; Vogel, 2012). According to Kelly (1955-1991), people's tendencies or personal constructs determine the way people interact with incidents, roles, approaches towards other people and behavior. The world is signified and controlled by these personal structures.

Counselors' personal structures about their own profession have been understudied particularly through repertory grid technique. In a study employing this technique, Wheeler (2000) analyzed the repertory grids of 27 experienced counselor trainers and examined the way in which the counselor trainers distinguished between good and bad apprentice counselors. The data showed that the counselor trainers described the trainee counselors mostly as open-closed, accessible-distant, reliable-unreliable, or professionally qualified or unqualified. However, professional competence is counselor trainers most frequently referred personal construct to distinguish between good trainees and bad trainees. These professional qualifications involve listening skills, tolerance in expressing emotions and the awareness of other 
peoples' necessities. The other structures are divided into two groups which are responsibility and being able to receive feedbacks. In a secondary more detailed assessment, it has been determined that the qualifications specifically related to counseling are the personal constructs used by counselor trainers to distinguish between good and bad trainees (Wheeler, 2000).

Wheeler's (2000) findings are ideographic in nature. However, his work, as many other researchers also opted for these kinds of studies, presents information merely about outsider perspective. Yet, this study attaches priority to gaining information from counselors insider perspective as a procedural preference. Additionally, these personal constructs representing ideal counselors have been attempted to be categorized within this scope of research. For that purpose, this study refers to Beutler, Machado and Neufeld's (1994) classification system of counselor qualifications given in detail below.

This classification system has been analyzed and undergone some changes during the following years (Beutler et al., 2004). In this classification system, therapist qualities are divided into four categories: observable traits and states, inferred traits and states. Age, gender and ethnic relation are the variables of the observable traits whereas therapeutic style and experience involve observable states. In inferred traits, there are non-temporal traits and characteristics of counselors, which are not possible to learn through direct observation and qualities of self-esteem, self-acceptance, calmness, coping strategies and patience. In addition, values, sexual orientation, wellness level and general attitudes that might have an effect on the counselor are represented in this category. The last category of inferred states consists of variables such as valuing clients and building therapeutic relations. Sincerity, empathy and authenticity often named as rogerian-variables are examined in this category. Besides, counselors expectations from their clients and their attitudes are other important variables assessed in this category (Beutler et al., 1994; Beutler et al., 2004).

A lack of clear findings on how counselors see effective counselors and themselves as a professional has been considered a problem. In addition, the main rationale of this study is justified by the fact that no finding as to how distant counselors see themselves from their ideal counselor image. Therefore, research into counseling education and supervision is considered to contribute to the field.

\subsection{Aim of the Study}

The main aim of this explorative study is to shed light on personal constructs utilized by psychological counselors while they characterize themselves as a psychological counselor, ideal-self, ideal and non-ideal psychological counselor through repertory grid technique. Within this general framework, answers are sought for these questions:

1. Which personal constructs are used by counselors when they characterize counselors?

2. Which personal constructs obtained after the analysis best match with the effective counselor profile?

3. How can counselors and personal constructs matched with effective counselor profile be classified theoretically?

4. Does the distance between the current perception of the participants as counselors towards themselves and the elements of being would-be ideal, ideal and non-ideal counselors differ significantly?

\section{Methodology}

This research is designed as a quantitative case analysis model as well as descriptive and multi case study (Bortz \& Döring, 2006). The information about how the counselors represent self and effective counselors characteristics in their cognition is elicited by analysis of each participant's repertory grid structures. Since this study focuses on internal validity rather than external validity, it is an explorative and ideographic study.

\subsection{Participants}

The participants are composed of 60 psychological counselors with minimum BA degree in Psychological Counseling and Guidance department who work in various cities in Turkey. $41(68 \%)$ of the volunteer counselors were female and $19(32 \%)$ of them were male. Working years of counselors ranged between 1 and 14 , and the average of their working year is 5.4. Further, $43 \%(\mathrm{n}=26)$ of counselors held BA, $42 \%(\mathrm{n}=25) \mathrm{MA}$ and $15 \%(\mathrm{n}=9) \mathrm{PhD}$ degrees.

\subsection{Procedure}

\subsubsection{Identification of Elements}

The identification of the elements in a repertory grid analysis is a primary issue. Accordingly, elements are "Self as a counselor, Ideal-self, two ideal and two non-ideal counselors" (see Table-1). Five of these counselors were real and one is hypothetical (Ideal-self). Ideal and non-ideal counselors are determined by the participants considering the real individuals. They were asked not to specify the real names of the people they chose and use pseudonym instead. 
Table 1. An example of Repertory Grid in this study

\begin{tabular}{|c|c|c|c|c|c|c|c|}
\hline $\begin{array}{l}\text { As a Counselor what are the } \\
\text { common features of two } \\
\text { psychological counselors } \\
\text { shown with "X"? }\end{array}$ & 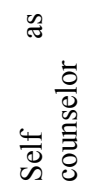 & $\begin{array}{l}\frac{4}{0} \\
\frac{1}{1} \\
\frac{0}{0} \\
\frac{0}{0}\end{array}$ & 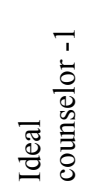 & 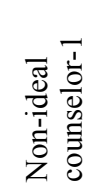 & 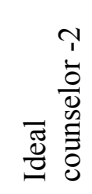 & 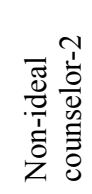 & $\begin{array}{l}\text { What is the difference of the } \\
\text { counselor marked with "O" } \\
\text { from two psychological } \\
\text { counselors marked with X? }\end{array}$ \\
\hline & $\mathrm{O}$ & $\mathrm{X}$ & $\mathrm{X}$ & & & & \\
\hline & $\mathrm{O}$ & & $\mathrm{X}$ & X & $\begin{array}{l}\mathrm{O} \\
\mathrm{X}\end{array}$ & $X$ & \\
\hline & & $\mathrm{O}$ & & X & & X & \\
\hline & & & $\mathrm{O}$ & $\mathrm{X}$ & & $\mathrm{X}$ & \\
\hline & & & $X$ & & $\mathrm{X}$ & $\mathrm{O}$ & \\
\hline & & $\mathrm{X}$ & $X$ & $\mathrm{O}$ & & & \\
\hline & X & & $\mathrm{O}$ & & & $X$ & \\
\hline
\end{tabular}

\subsubsection{Eliciting Personal Constructs}

Every participant in the study group compares the elements in the grid matrix grouped as three. For example, two counselors who took part in the study were asked to associate each other by using a feature (for example "the Ideal-self" and "number 1 ideal counselor") and again the third element (for example "self as a counselor") specifies a contrasting element and distinguish it from the other two similar elements. Accordingly, six elements, with various combinations were compared eight times. Thus, for each participant's repertory grid example, eight constructs arose along with their different constructs. In addition, a construct (effective-ineffective) is added to the constructs by the researcher. Hence, the number of each repertory grid example reached nine constructs in total.

\subsubsection{Evaluating Elements}

The participants were asked to evaluate each element in terms of constructs obtained from the previous stage (e.g. monotone-creative). Participants evaluated the elements for each construct on the five scale (see Table-2). This means that low value elements are seen as negative, and high values are seen as positive. Following the evaluation of each element for each construct, data analysis process was performed.

Table 2. An example of Repertory Grid in this study

\begin{tabular}{|c|c|c|c|c|c|c|c|}
\hline & 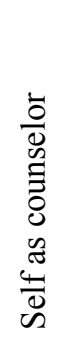 & 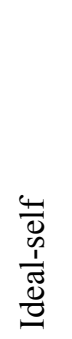 & 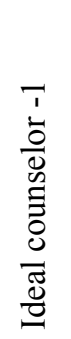 & 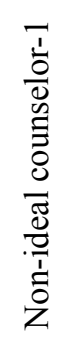 & 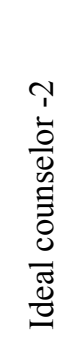 & 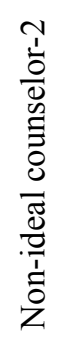 & \\
\hline Ineffective listening & 4 & 5 & 5 & 1 & 5 & 2 & Effective listening \\
\hline Panicked & 3 & 5 & 5 & 1 & 4 & 1 & Keeping calmness \\
\hline Unenthusiastic- cold & 4 & 5 & 4 & 1 & 4 & 2 & Active participation-affiliation \\
\hline Resenting the client & 4 & 5 & 5 & 2 & 5 & 1 & Emotion control for the client \\
\hline Not managing process & 4 & 5 & 5 & 2 & 5 & 2 & $\begin{array}{l}\text { Testing the hypothesis } \\
\text { appropriately }\end{array}$ \\
\hline Not understanding the client & 4 & 5 & 5 & 1 & 5 & 1 & Effective empathy skill \\
\hline Running the process monotonously & 3 & 5 & 5 & 1 & 4 & 1 & Usage of method-technique \\
\hline $\begin{array}{r}\text { Failure to comply with the } \\
\text { appointments }\end{array}$ & 3 & 5 & 5 & 2 & 5 & 3 & $\begin{array}{l}\text { Ability to comply with the } \\
\text { appointments }\end{array}$ \\
\hline Ineffective & 4 & 5 & 5 & 1 & 5 & 2 & Effective \\
\hline
\end{tabular}




\subsection{Data Analysis}

To analyze the obtained repertory grids Rep IV 1.12 version was used (Gaines \& Shaw, 2005). Constructs of each participant's repertory grid (also called as a focus grid) reveals the hierarchical cluster analysis results. Repertory grid constructs show the relation between elements and constructs through a graph. Clusters which consist of elements and constructs can be identified. Finally, the distance between those clusters was statistically tested (paired sample t-test).

\section{Results}

\subsection{Repertory Grid Structure}

The repertory grid structure of one participant of this study (also focus grid) is shown as a sample below.

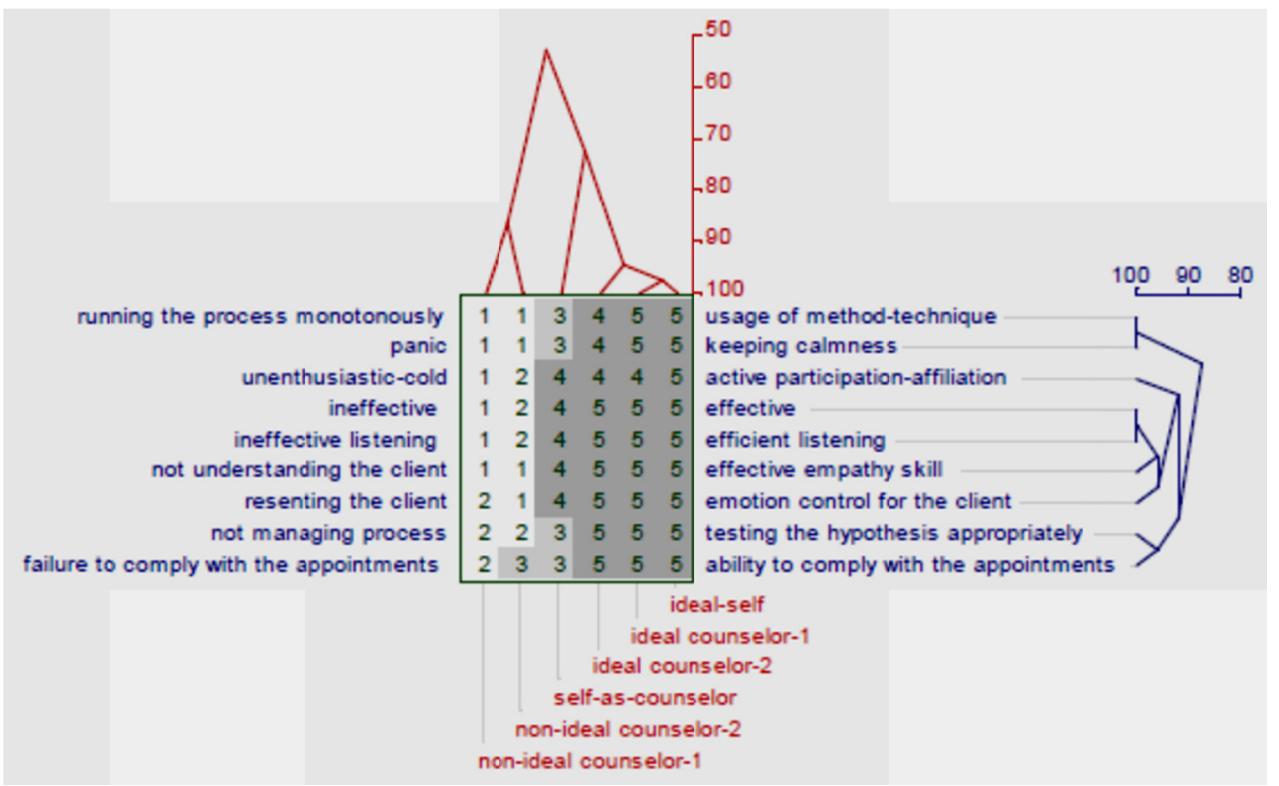

Figure 1. Focus: Case BA; Elements: 6; Constructs: 9; Range: 1 to 5; Context: Personal Constructs of Counselors

Examining the dendrogram in Figure 1, both non-ideal counselors constitute one cluster and one of the ideal counselors and the element of "ideal-self" form another cluster. It is seen that ideal counselor no 2 stands close to this cluster. Considering the percentage chart, the participant BA almost completely associates the element of ideal-self with the first ideal counselor. Similarly, BA almost completely associates the non-ideal counselors. In contrast, the element of "self-as-a counselor" is seen not to match with the other two clusters very closely. Nevertheless, BA sees himself closer to ideal counselors than non-ideal counselors.

The dendrogram at the right of the figure, likewise, points to the similarity between the constructs. Examining this dendrogram, it is seen that the constructs of ineffective-effective and inefficient listening-efficient listening are entirely matched, and running the process monotonously-usage of technique and panicked-keeping calmness are entirely matched by BA. Two dimensional constructs not managing the process-testing the hypothesis appropriately regarding the process composes a closed cluster by being associated with the two dimensional constructs failure to comply with the appointments-ability to comply with the appointments. Not understanding the client-advanced empathy skill, resenting the client-emotion control for the client, unenthusiastic-cold- active participation/affiliation are observed not to have matched in a cluster.

As a result of comparing six elements, 480 (60x8) personal constructs were obtained in total. All personal constructs obtained were classified according to the classification system of counselor characteristics by Beutler et al. $(1994 ; 2004)$. Column 2 of the Table 3 displays the frequencies and percentages of the constructs 60 participants used.

\subsection{Personal Constructs Matching Most with the Trait of "Being Effective" of a Counselor}

Which of these constructs are associated with the effective counselor was also analyzed. Column 3 of Table 3 shows the frequencies and percentages of the constructs most related to the effective counselor.

Each participant's repertory grid structure was elicited to determine which personal constructs were matched most to being effective construct. For this, focus grid of each participant was revealed (typical focus grid was shown in Figure 1). Elements in the example are rated 1, 2, 4, 5,5 in terms of effective construct. It is seen that this construct is most related to effective listening construct. 
As it is apparent in Table 3, rates do not equal to $100 \%$. It is because all constructs obtained from one participant sometimes belong to only one category. For instance, all eight constructs elicited from one participant (coping with stress effectively-failure to cope with stress, self-confident-low self-confidence, calm-nervous, extrovert-introvert and the like) were involved in inferred traits whereas all the categories expressed by another participant (professional qualification, professional background, therapeutic style, experience and the like) were found to be in observable-states.

Table 3. Personal Constructs Presented by Psychological Counselors through Repertory Grid Analysis

\begin{tabular}{|c|c|c|}
\hline Personal Constructs & $\begin{array}{l}\text { Percentages and Frequencies (in } \\
\text { parentheses) of the Constructs } \\
\text { Elicited from the Participants } \\
(\mathrm{N}=60)\end{array}$ & $\begin{array}{l}\text { Percentages and Frequencies about } \\
\text { the Participants' }(\mathrm{N}=60) \text { Evaluation } \\
\text { of the Constructs in terms of being } \\
\text { "Effective" }\end{array}$ \\
\hline Age, gender, Ethnicity & $0.2(1)$ & - \\
\hline Observable Traits & $0.2(1)$ & - \\
\hline $\begin{array}{l}\text { Personal traits, coping skills, emotional } \\
\text { well-being, self-confidence etc. }\end{array}$ & $19.8(95)$ & $20.7(23)$ \\
\hline $\begin{array}{l}\text { Values, attitudes, objectivity, view of life, life } \\
\text { philosophy etc. }\end{array}$ & $15.6(75)$ & $18.0(20)$ \\
\hline Inferred Traits & $35.4(170)$ & $38.7(43)$ \\
\hline $\begin{array}{l}\text { Therapeutic intervention, therapeutic style, } \\
\text { therapeutic orientation }\end{array}$ & $10.2(49)$ & $12.6(14)$ \\
\hline $\begin{array}{l}\text { Professional qualification, professional } \\
\text { background, professionalism, experience }\end{array}$ & $24.8(119)$ & $27.9(31)$ \\
\hline Observable States & $35.0(168)$ & $40.5(45)$ \\
\hline $\begin{array}{llll}\text { Rogerian } & \text { variables } & \text { and } & \text { therapeutic } \\
\text { relationship }\end{array}$ & $19.0(91)$ & $17.1(19)$ \\
\hline Expectations and attitudes towards client & $6.5(31)$ & $0.9(1)$ \\
\hline $\begin{array}{l}\text { Social influence (expertise, reliability, } \\
\text { attractiveness) }\end{array}$ & $4.0(19)$ & $2.7(3)$ \\
\hline Inferred States & 29.4 (141) & $20.7(23)$ \\
\hline
\end{tabular}

Constructs about elements used by counselors are mostly in professional qualification, professional background, professionalism and experience $(\mathrm{n}=119 ; 25 \%)$, personal traits, coping skills, emotional well-being, self-confidence $(\mathrm{n}=95 ; 20 \%)$ respectively. Those categories are followed by the constructs in rogerian variables, therapeutic relationship $(\mathrm{n}=91 ; 19 \%)$ and values, attitudes, objectivity, view of life, life philosophy $(\mathrm{n}=75 ; 16 \%)$. Constructs used in these categories such as therapeutic intervention, therapeutic style and therapeutic orientation $(\mathrm{n}=49 ; 10 \%)$ are used relatively less by counselors. Likewise, constructs categorized as expectations and attitudes towards the client $(\mathrm{n}=31 ; 6 \%)$, and social influence $(\mathrm{n}=19 ; 4 \%)$ have a low percentage. Only one construct which can be evaluated in age, sex and ethnicity is used by counselors.

Column 3 of the table 3 shows which of the personal constructs about ideal and non-ideal counselors in terms of being effective preferred by participants matches most. According to this, effectiveness of counselor most match with the constructs of professional qualification, professional background, professionalism and experience $(\mathrm{n}=31 ; 28 \%)$, personal traits, coping skills, emotional well-being, self-confidence $(\mathrm{n}=23 ; 21 \%)$ categories respectively. They are followed by values, attitudes, objectivity, view of life, life philosophy $(\mathrm{n}=20 ; 18 \%)$ and rogerian variables, therapeutic relationship $(\mathrm{n}=19 ; 17 \%)$. The constructs in therapeutic intervention, therapeutic style and therapeutic orientation $(\mathrm{n}=14$; $13 \%)$ are matched relatively less about the effectiveness of the counselors. Only three of used personal constructs matched with social effect and one of them matched with expectations and attitudes towards the client.

\subsection{Analysis of Cluster Distances among the Elements}

Paired samples t-test was performed to analyze whether the distance between elements was significant or not. Results of the analysis indicated that the distance was significant between the element cluster of self-as-a counselor and ideal-self and the clusters composed of both ideal $(t=14.409 ; \mathrm{df}=59 ; \mathrm{p}<.01)$ and similarly both non-ideal $(t=6.962 ; \mathrm{df}=59 ; \mathrm{p}$ $<.01)$ counselors.

\section{Discussion}

This study aimed to identify professional images of the counselors as a member of this profession and what kind of personal constructs they referred to while expressing effective counselor image through repertory grid technique. The results manifest that constructs characterizing the image related to the counselor have a balanced distribution in terms of the classification system characterizing a counselor by Beutler et al. (1994; 2004). Accordingly, all categories except for observable-traits (age, gender, and ethnicity) are seen to represent the counselor image almost equally. Personal constructs used for counselors have a balanced distribution in terms of the classification system about counselor features by Beutler et al. (1994; 2004). 
Considering which personal constructs are matched with counselors' being effective, observable states such as professional quality, experience and therapeutic style are more emphasized by the participants. This category is followed respectively by inferred traits involving personality traits, values, attitudes and life philosophy of the counselor and inferred states including rogerian variables expectations and attitudes towards the client.

The frequent use of professional qualification, professional backgrounds, professionalism and experience features implies that participants may have attributed the professional qualification to the education and experience dimensions. However, according to Laireiter and Botermans (2005), education alone does not guarantee the qualification of a counselor. According to Laireiter and Botermans (2005), the education needs to fulfill the required standards and needs to be associated with a specific problem domain. Education will be helpful for effective counselors only if all these requirements are fulfilled (Laireiter \& Botermans, 2005). Experience is one of the mostly used constructs in education. Margraf and Baumann (1986) note that psychotherapists do not attribute great significance to experience for their professional development; however, the effect of this variable on the clients has not been proven completely. Experience often referred to being an effective counselor probably enables them to feel better. To perceive themselves as an unqualified counselor merely reflect the immediate situation. The possible reason for expressing experience so often is to reinforce self-belief about compensating for their deficiencies in the future. Yet, as Beutler (1997) points out, time or rather age does not always guarantee experience.

Subsequent to professional qualification, professional background, professionalism and experience, personal traits, coping skills, emotional well-being and self-confidence" is the most emphasized second sub-category. The relationship between the personal traits of the counselor and therapeutic success has not been enlightened precisely so far (Beutler et al., 2004). However, current studies suggest that personal traits of the counselor play a role on the therapeutic success (Lafferty, Beutler \& Crago, 1989; Luborsky et al., 1986). Nonetheless, what kind of personal traits provide advantages for the counselor in gaining therapeutic success is a matter of debate that cannot be completely settled yet. The fact that experienced counselors who provide counseling training often put an emphasis on personal traits such as open-close, accessible-distant, reliable-unreliable while distinguishing good and bad counselors indicates how determining the personal traits are (Wheeler, 2000).

The third most frequently referred personal construct by the participants while characterizing the psychological counselor is rogerian variables (intimacy, warmth, unconditional acceptance and empathy) and therapeutic relationships. Studies reveal that variables most associated with therapeutic success are included in this group. Variable which is the mostly-examined and proven to be effective in terms of counseling process and outcome is therapeutic relationship among these variables. As a matter of fact, Norcross (2002) points out that therapeutic relationship has 30\%; applied therapeutic strategy and technique, expectations of clients $15 \%$, and extra therapeutic events such as clients' having a positive living environment $40 \%$ impact upon the therapeutic success. Likewise, some researchers put forward that therapeutic relationship (Baldwin, Wampold \& Imel, 2007; Orlinsky, Grawe \& Parks, 1994; Tryon \& Winnograd, 2001) and therapeutic alliance (Emmerling \& Whelton, 2009; Grawe, 2000) provide a considerable contribution in terms of therapy success. Willutzki and Laireiter (2005) specify that good psychotherapists can distinguish how important the therapeutic relationship is in terms of psychotherapy process and outcome. According to Stiles, Shapiro and Elliot (1986), therapeutic relationship is a variable that makes difference since it serves person to view himself/herself valuable.

Another personal construct that the participants frequently utilize while representing the counselors and effective counselor in general is "values, attitudes, objectivity, view of life, life philosophy" which seems to be directly associated with the counselor's personality. These variables are thought to be related to therapeutic success; however, it can be said that studies supporting this are insufficient. Nevertheless, limited number of studies indicate that psychotherapist's homosexuality, bisexuality or negative attitude towards the old people influence the therapeutic success negatively (Beutler et al., 2004). Therefore, counselor should be sensitive to different individuals and cultures or strive to know them better. In other words, his/her tolerant attitude to different lifestyles holds significance in terms of his/her professional identity development (Kanfer, Reinecker \& Schmelzer, 1996).

The other personal construct frequently characterizing counselors and more specifically effective counselor is the features concerning therapeutic intervention, therapeutic style and therapeutic orientation. Najavits and Strupp (1994) assert that effective counselors/psychotherapists exhibit more positive and in contrast less negative behaviors than the ineffective ones during the session. Positive behavior implies counselor's being warm, approving, understanding, supportive and protective; negative behavior hints at counselor's taking an attitude that leads to clients' feeling worthless. Furthermore; blaming, disregarding and neglecting the clients are evaluated to be in negative behavior category (Najavits \& Strupp, 1994). Plentiful studies propound that therapeutic style has a positive relationship with psychotherapy outcomes (Beutler et al., 2004). Together with therapeutic style, selection of methods or intervention suitable for the clients holds a critical importance. In fact, Wampold (2001) and Revenstorf (2009) state that appropriateness of the used or applied method is 
related to the counseling outcomes. However, Willutzki and Laireiter (2005) set forth that therapeutic interventions (different schools), one of the variables which has been the most frequent research area in psychotherapy investigations so far, do not display a very strong relation with the therapeutic success. In fact, there are a lot of research findings that show different theoretical orientations (Stiles, Shapiro \& Elliott, 1986; Orlinsky \& Ronnestad, 2005).

Relatively the least referred personal constructs by the participants as a counselor were "expectations and attitudes towards the clients" and the counselor's "expertise, reliability and attractiveness (social influence)" which are in fact social psychological variables. However, research findings indicate that counselor's attitude towards the client is important (Beutler et.al., 1994). Likewise, despite being limited, study results display that variables related to social influence have a positively significant relationship with the client satisfaction (McNeil, May \& Lee, 1987).

The most controversial features in the classification developed by Beutler et al. (1994; 2004) was the one with the observable and continuous features implying the counselor's age, gender and ethnicity. In fact, the results of this study found out that almost no participant characterized the counselors with these features. Beutler, Machado and Neufeldt (1994) note that findings pertinent to age, gender and ethnicity display inconsistency; even though it does not present a central importance, the match between the counselor and the client provides more significant results than these variables.

As a consequence, participants associated the effective counselor with the features in the states most. Constructs associated with especially the effective counselor most stand out to be the professional qualification, professional backgrounds, experience, therapeutic style and therapeutic orientation; In fact, it seems that all these characteristics can be gained and improved in time. The reason for these characteristics elicited by the participants frequently may stem from the fact that these characteristics can be controlled by their efforts and be compensatory in time. Though these qualities are not acquired, the opinion that these features can be learned in time offers an opportunity for them (counselors) to develop a positive professional projection. Rogerian variables, another state category and comprising therapeutic relationship, counselor expertise, reliability, attractively, expectations and attitudes towards the client were associated with the effective counselor relatively low. However, the effect of these variables on therapeutic success is supported by empirical research. Therefore, the expectation was that these variables could be more likely to be associated with the characteristic of being an effective counselor. It may result from the fact that counselors have insufficient knowledge in therapeutic processes or do not have projections on how to implement it during the process.

All the features in the state category can be acquired through training and effort; however, current studies manifest that counselor's personality, coping skills, self-confidence, values, attitudes and views of life have a pivotal impact on the therapeutic success (Lafferty, Beutler \& Crago, 1989; Luborsky et. al., 1986; Tscheulin, 1982; Wheeler, 2000). In fact, Jennings and Skovholt $(1999 ; 2004)$ note that education may not be determinant alone in training a master psychological counselor and state how important these personal traits of the counselors as individuals when they become professional. As a matter of fact, the number of the personal traits associated with the effective counselor was found to be significant in this study.

Another important finding of this study was that the distance between the self-perceptions and future projections of the participants as a counselor and other element clusters (ideal and non-ideal psychological counselors) differed significantly. These results mean that participants view themselves distant from both the ideal and non-ideal counselors. The findings show that participants are not satisfied with their state as a counselor or they are in need of improving themselves. However, previous findings indicate that the participants prioritize professional quality, training and experience as determining aspects for an ideal counselor. Yet, it is known that findings about these variables are not very clear as stated before. However, improving counselors to establish therapeutic relationship and basic helping skills is likely to render their construct of themselves more positive.

\section{Conclusion}

Research findings point out that the qualities of ideal counselors are mostly the ones in the inferred-state (rogerian variables, therapeutic relationships, attitudes towards the client and expectations, social influence etc.). Yet, it is claimed that the findings about education and experience in the qualifications of counselors are not clear or that these variables could be effective when they meet certain standards and conditions. The findings show that it is future training and experience, which are personal constructs, which are most frequently used by the participants while determining the ideal counselor. The participants are of the opinion that there is a gap between the qualities they possess, their ideal counselor image and ideal and non-ideal counselor qualities. Consequently, participants -as members of professions- differentiate themselves and their ideal counselor image from the ideal and non-ideal counselors. In fact, this finding indicates that the participants actually have an idea about what kind of person they do not want to become; yet, it also makes it questionable whether they really take ideal counselors as role models for themselves.

During their undergraduate and postgraduate education, counselors could have missed out on some opportunities to 
observe their supervisors or skilled counselors who may have been possible role models for them and this situation might have bred such a result. Hence, they evaluate these role models on the basis of observable factors such as education and experience rather than their therapeutic success. Thus, applied courses need to be emphasized in both undergraduate and post graduate studies in Psychological Counseling and Guidance Programs. These applied courses are believed to be more effective in developing insight when they are based on evidence. Additionally, when counselor candidates are provided with more role models, they will develop a better understanding of what type of counselors they want to become.

\section{References}

Baldwin, S. A., Wampold, B. E., \& Imel, Z. E. (2007). Untangling the alliance-outcome correlation: Exploring the relative importance of therapist and patient variability in the alliance. Journal of Consulting and Clinical Psychology, 75, 842-852. http://dx.doi.org/10.1037/0022-006X.75.6.842

Baumann, U. (1986). Zum Placebo-Konzept in der Psychotherapie. In H. Hippius, K. Überla, G. Laakmann \& J. Hasford (Hrsg.), Das Placebo-Problem (pp. 97-105). Stuttgart: Fischer.

Beutler L. E., Machado, P. P. P., \& Neufeldt, S. A. (1994).Therapist Variables. In A. E. Bergin \&S. L. Garfield (Eds.) Handbook of Psychotherapy and Behavior Change (4th ed.) (pp.229-269). New York: Wiley.

Beutler, L. E., Malik, M., Alimohamed, S., Harwood, T. M., Talebi, H., Noble, S., \& Wong, E. (2004).Therapist Variables. In Lambert, M. J. Bergin and Garfield's Handbook of Psychotherapy and Behavior Change (5th ed.) (pp.227-306). New York: Wiley.

Blatt, S. J., Sanislow, C. A., Zuroff, D. C., \& Pilkonis, P. A. (1996). Characteristics of effective therapists: Further analyses of data from the National Institute of Mental Health treatment of depression collaborative research program. Journal of Consulting and Clinical Psychology, 64, 1276-1284. http://dx.doi.org/10.1037/0022-006X.64.6.1276

Crits-Christoph, P., \& Mintz, J. (1991). Implications of therapist effects for the design and analysis of comparative studies of psychotherapies. Journal of Consulting and Clinical Psychology, 59, 20-26. http://dx.doi.org/10.1037/0022-006X.59.1.20

Crits-Christoph, P., Baranackie, K., Kurcias, J. S., Beck, A. T., Carroll, K., Perry, K., Luborsky, L., McLellan, A. T., Woody, G. E., Thompson, L., Gallagher, D., \& Zitrin, C. (1991). Meta-analysis of therapist effects in psychotherapy outcome studies. Psychotherapy Research, 1, 81-91. http://dx.doi.org/10.1080/10503309112331335511

Dinger, U., Strack, M., Leichsenring, F., Wilmers, F., \& Schauenbirg, H. (2008). Therapist effects on outcome and alliance in inpatient psychotherapy. Journal of Clinical Psychology, 64(3), 344-354.

$\mathrm{http}: / / \mathrm{dx}$.doi.org/10.1002/jclp.20443

Frank, J. D. (1973). Persuasion and healing (2nd ed.). Baltimore: Johns Hopkins University Press.

Fransella, F., Bell, R., \& Bannister, D. (2004). A Manual for Repertory Grid Technique (2nd ed.). Chichester: John Wiley $\&$ Sons.

Fromm, M. (1995). Repertory Grid Methodik - Ein Lehrbuch. Weinheim: Deutscher StudienVerlag.

Fromm, M. (2002). Was sind Repertory Grid Methoden? In E. König, P. Zedler (Hrsg.), Qualitative Forschung (pp. 195-212). Weinheim: Beltz.

Garfield, S. L. (1997). The therapist as neglected variable in psychotherapy research. Clinical Psychology: Science and Practice, 4, 40-43.http://dx.doi.org/10.1111/j.1468-2850.1997.tb00097.x

Grawe, K., Donati, R., \& Bernauer, F. (1994). Psychotherapie im Wandel. Von der Konfession zur Profession. Göttingen: Hogrefe.

Huf, A. (1992). Psychotherapeutische Wirkfaktoren. Weinheim: Psychologie-Verl.-Union.

Jennings, L., \& Skovholt, T. M. (1999).The cognitive, emotional, and relational characteristics of master therapists. Journal of Counseling Psychology, 46, 3-11. http://dx.doi.org/10.1037/0022-0167.46.1.3

Kanfer, F. H., \& Goldstein, A. P. (1991). Helping people change. New York: Pergamon Press.

Kanfer, F. H., Reinecker, H., \& Schmelzer, D. (1996). Selbstmanagement-Therapie-ein Lehrbuch für die klinische Praxis (2nd ed.). Heidelberg: Springer.

Kelly, G. A. (1955/1991). The psychology of personal constructs. New York: Routledge.

Lafferty, P., Beutler, L. E., \& Crago, M. (1989). Differences between more and less effective psychotherapists: A study of select therapist variables. Journal of Consulting and Clinical Psychology, 57(1), 76-80. http://dx.doi.org/10.1037/0022-006X.57.1.76

Laireiter, A. R., \& Botermans, J. F. (2005). Ausbildungsforschung in der Psychotherapie. In A.-R.Laireiter \& U. Willutzki (Hrsg.), Ausbildung in der Verhaltenstherapie (pp. 53-101). Hogrefe-Verlag Göttingen. 
Lambert, M. J. (1992).Implications of outcome research for psychotherapy integration. In J.C. Norcross \& M.R. Goldfried (Eds.) Handbook of psychotherapy integration (pp. 94-129). New York: Wiley.

Larson, L. M., \& Daniels, J. A. (1998). Review of the counseling self-efficacy literature. The Counseling Psychologist, 26(2), 179. http://dx.doi.org/10.1177/0011000098262001

Luborsky, L., Crits-Christoph, P., McLellan, A. T., Woody, G., Piper, W., Liberman, B., Imber, S., \& Pilkonis, P. (1986). Do therapists vary much in their success? Findings from four outcome studies. American Journal of Orthopsychiatry, 56, 501-512. http://dx.doi.org/10.1111/j.1939-0025.1986.tb03483.x

Mayring, R. (2000). Nitel Sosyal Araştırmaya Giriş (Çev., A. Gümüş \& M.S. Durgun), Adana: Baki Kitapevi.

McNeill, B. W., May, R. J., \& Lee, V. E. (1987). Perceptions of counselor source characteristics by premature and successful terminators. Journal of Counseling Psychology, 34, 86-89. http://dx.doi.org/10.1037/0022-0167.34.1.86

Norcross, J. C. (2002). Empirically supported therapy relationships. In J. C. Norcross (Ed.), Psychotherapy relationships that work. Therapist contributions and responsiveness to clients (pp. 3-17). New York: Oxford University Press.

Norcross, J. C., \& Prochaska, J. O. (1982). A national survey of clinical psychologists: Views on training, career choice, and APA. The Clinical Psychologist, 35(4), 4-8.

Okiishi, J., Lambert, M. J., Nielsen, S. L., \& Ogles, B. M. (2003). Waiting for supershrink: An empirical analysis of therapist effects. Clinical Psychology \& Psychotherapy, 10(6), 361-373. http://dx.doi.org/10.1002/cpp.383

Orlinsky, D. E., Grawe, K., \& Parks, B. K. (1994). Process and outcome in psychotherapy: Noch einmal. In A.E. Bergin \& S. L. Garfield (Eds.), Handbook of psychotherapy and behavior change (pp. 270-329). New York: Wiley.

Retsas, A., \& Wilson, J. (1997). Effective' Australian gerontology nurses: a repertory grid analysis. Journal of Clinical Nursing; 6, 269-276. http://dx.doi.org/10.1111/j.1365-2702.1997.tb00315.x

Scheer, J. W. (1993). Planung und Durchführung von Repertory Grid-Untersuchungen. In J.W. Scheer \& A. Catina (Hrsg.), Einführung in die Repertory Grid-Technik. Grundlagen und Methoden (Volume. 1, pp. 24-40). München.

Sherman, M., \& Thelen, M. (1998). Distress and professional impairment among Psychologists in clinical practice. Professional Psychology: Research \& Practice, 29(1), 79-85. http://dx.doi.org/10.1037/0735-7028.29.1.79

Skovholt, T. M., \& Jennings, L. (Eds.) (2004).Master therapists: Exploring expertise in therapy and counseling. Boston: Allyn \& Bacon.

Skovholt, T. M., \& Rønnestad, M. H. (1995). The evolving professional self: Stages and themes in therapist and counselor development. New York, NY: Wiley.

Stiles, W. B., Shapiro, D. A., \& Elliott, R. (1986). Are all psychotherapies equivalent? American Psychologist, 41, 165-180. http://dx.doi.org/10.1037/0003-066X.41.2.165

Teyber, E., \& McClure, F. (2000).Counselor variables. In C.R. Snyder \& R.E. Ingram (Eds.), Handbook of Psychological Change: Psychotherapy Processes \& Practices for the 21st Century (pp. 62-87). New York: Wiley \& Sons.

Tscheulin, D. (1982). Therapeutenmerkmale in der Psychotherapie. In: R. Bastine, P. A. Fiedler, K. Grawe, S. Schmidtchen \& C. Sommer (Hrsg.), Grundbegriffe der Psychotherapie. Weinheim: Edition Psychologie.

Tyron, G., \& Winograd, G. (2002). Goal consensus and collaboration. In J. C. Norcross (Ed.), Psychotherapy relationships that work (pp. 109-128). New York: Oxford University Press.

Vogel, M. (2012). Das Repertory-Grid-Interview für systemische Forschungsvorhaben. In Ochs, M. \& Schweitzer, J. (Hg.), Handbuch Forschung für Systemiker. (pp. 381-394). Göttingen: Vandenhoeck \& Ruprecht. http://dx.doi.org/10.13109/9783666404443.381

Wampold, B. E., \& Bolt, D. M. (2006). Therapist effects: Clever ways to make them (and everything else) disappear. Psychotherapy Research, 16, 184-187.http://dx.doi.org/10.1080/10503300500265181

Wheeler, S. (2000). What makes a good counselor? An analysis of ways in which counselor trainers construe good and bad counselling trainees. Counselling Psychology Quarterly, 13, 65-83.

http://dx.doi.org/10.1080/09515070050011079

Willutzki, U., \& Laireiter, A. R. (2005). Ausbildung in der Verhaltenstherapie - Was ist ein guter (Verhaltens) therapeut und wie soll Ausbildung gestaltet sein?. In A.R. Laireiter \& U. Willutzki (Hrsg.). Ausbildung in der Verhaltenstherapie (pp. 21-49). Hogrefe-Verlag Göttingen.

\section{(cc) EY}

This work is licensed under a Creative Commons Attribution 3.0 License. 